\title{
The nutritional composition of fennel (Foeniculum vulgare): Shoots, leaves, stems and inflorescences
}

\author{
Lillian Barros, Ana Maria Carvalho, Isabel C.F.R. Ferreira* \\ Centro de Investigação de Montanha (CIMO), ESA, Instituto Politécnico de Bragança, Campus de Santa Apolónia, Apartado 1172, $5301-855$ Bragança, Portugal
}

\section{A R T I C L E I N F O}

\section{Article history:}

Received 22 June 2009

Received in revised form

22 December 2009

Accepted 12 January 2010

\section{Keywords:}

Fennel

Macronutrients

Sugars

$\omega 3$ and $\omega 6$ Fatty acids

\begin{abstract}
A B S T R A C T
The chemical composition and the nutritional value of different parts of Foeniculum vulgare (fennel): shoots, leaves, stems and inflorescences, were determined. The evaluation of chemical composition included the determination of moisture, total fat, crude protein, ash, carbohydrates, and nutritional value. The composition in individual sugars was determined, being fructose and glucose the most abundant sugars. The analysis of fatty acid composition, allowed the quantification of twenty one fatty acids. Polyunsaturated fatty acids were the main group in all the fennel parts; linoleic acid predominated in shoots, stems and inflorescences, while $\alpha$-linolenic acid predominated in leaves. The higher levels of $\omega-3$ fatty acids found in leaves contributed to its lowest ratio of $\omega-6$ to $\omega-3$ fatty acids. Also, the lower levels of $\omega-3$ fatty acids found in inflorescences contributed to its highest ratio of $\omega-6$ to $\omega-3$ fatty acids.
\end{abstract}

(c) 2010 Elsevier Ltd. All rights reserved.

\section{Introduction}

Fennel (Foeniculum vulgare Mill.) is a hardy, perennial, umbelliferous (Apiaceae) herb generally considered native to the Mediterranean areas that has become widely naturalised elsewhere; actually it may be found growing feral in many parts of the world. Fennel is highly aromatic with a characteristic aniseed flavour. Ethnobotanical data currently available on wild useful plants in Portugal highlight the importance of fennel' culinary and medicinal uses (Camejo-Rodrigues, Ascensão, \& Bone, \& Vallès, 2003; Carvalho, 2005; Novais, Santos, Mendes, \& Pinto-Gomes, 2004; Santayana et al., 2007; Veigas, 2007). Roots, young shoots, leaves, flowering stems, mature inflorescences and fully ripened and dried seeds are commonly used for homemade remedies, being useful in the treatment of several complaints, specifically those of the digestive system. Fennel is also highly recommended for diabetes, bronchitis and chronic coughs, for the treatment of kidney stones, and is considered to have diuretic, stomachic and galactogogue properties (Camejo-Rodrigues et al., 2003; Carvalho, 2005; Novais et al., 2004; Salgueiro, 2004).

Different fennel parts are widely used in many of the culinary traditions of the world and particularly in Portugal (Table 1). Shoots, tender leaves and stems are chewed and sucked due to its exquisite aniseed flavour. All these parts are also commonly used as vegetables. They are added raw to salads, stewed with beans and

\footnotetext{
* Corresponding author. Tel.: +351 273 303219; fax +351 273325405

E-mail address: iferreira@ipb.pt (I.C.F.R. Ferreira).
}

chickpeas, used to stuff fish for grilling, put in soups and in traditional fish and bread bouillons. Besides seasoning, fennel is used to preserve food: stems are sometimes one of the ingredients of the brines prepared for olives' cure; leafy stems are boiled in the water where figs are soaked before being dried. Flowering stems, sugar and honey macerating in brandy produce a highly valorised spirit. Herbal teas prepared with fresh tender or dried flowering stems are drunk chilled or hot, depending on the season (Carvalho, 2005; Santayana et al, 2007; Tardío, Pardo de Santayana, \& Morales, 2006; Tardío, Pascual, \& Morales, 2005; Veigas, 2007). The culinary use and therapeutic effects of fennel were so large that it has been exported from country to country for centuries (Oktay, Gülçin, \& Küfrevioğlu, 2003).

Fennel culinary value might be related to its organoleptic properties such as aroma and flavour, and also to its richness in carbohydrates, including sugars (Cataldi, Margiotta, \& Zambonin, 1998), minerals (Özcan \& Akbulut, 2007; Özcan, Ünver, Uçar, \& Arslan, 2008) and essential fatty acids (Vardavas, Majchrzak, Wagner, Elmadfa, \& Kafatos, 2006). Carbohydrates are important as short-term energy-storage compounds and also as major structural compounds in plant cell walls. Sugars such as glucose and fructose occupy key roles in energy metabolism and supply carbon skeletons for the synthesis of other compounds (Zubay, 2006). Polyunsaturated fatty acids from omega- 6 and omega- 3 families have strong biological properties in low concentrations (Gibney, Vorster, \& Kok, 2002) and are biosynthetic precursors of eicosanoids (i.e. prostaglandins), which are signalling molecules with complex control over many body systems, having effects on cardiovascular 
Table 1

Uses of fennel as food as reported in Portuguese ethnobotanical studies.

\begin{tabular}{|c|c|c|}
\hline Portuguese Region & Local name & Plant part and edible uses \\
\hline Trás-os-Montes (northeast) & Fiolho, fionho, erva-doce & $\begin{array}{l}\text { Shoots, tender leaves and stems - snacks, salads, soups, stews, spices } \\
\text { Flowering stems - beverages, spirits, spices } \\
\text { Stems - brochettes, herbal teas } \\
\text { Seeds - spices, flavour for cakes, biscuits, sweets and chestnuts }\end{array}$ \\
\hline Arrábida and Açor (center) & Funcho, erva-doce & Seeds - flavour for cakes and pastries and for cooking chestnuts \\
\hline Alentejo and Algarve (south) & Funcho, fiolho, funcho-doce, funcho-amargo & $\begin{array}{l}\text { Shoots, tender leaves and stems - fried with eggs, omelettes, fish stuff, } \\
\text { stewed with different kinds of beans and chickpeas, fish and bread } \\
\text { bouillons, soups, sauces } \\
\text { Tender leafy stems - grilled fish and fish dishes in general } \\
\text { Seeds - spices, flavour for cakes, bread and biscuits, chestnuts } \\
\text { Whole plant - olives brines, figs preserves and for aromatizing brandy }\end{array}$ \\
\hline
\end{tabular}

diseases, triglycerides levels, blood pressure and arthritis (Zubay, 2006). A deficient intake of essential fatty acids can be responsible for many problems such as dermatitis, immunosuppression and cardiac dysfunctions (Kaplan, 1996). In the present study it is reported the valuable nutritional composition of different parts of $F$. vulgare (fennel) - shoots, leaves, stems and inflorescences particularly in sugars, monounsaturated, polyunsaturated and saturated fatty acids, total $\omega-3$ and $\omega-6$ fatty acids and $\omega-6$ to $\omega-3$ ratio. On the basis of the contents of moisture, proteins, fat, carbohydrates and ash, an estimation of their nutritional role was performed.

\section{Materials and methods}

\subsection{Samples}

Samples of shoots, leaves, stems and inflorescences were gathered in Bragança, Trás-os-Montes, north-eastern Portugal. The selected sites and gathering practices took into account local consumers gathering criteria for the use of fennel and the optimal growth stage. The plant material was collected in half shade sites at the edges of woods, in early spring (shoots), in June (leaves) and during and after the flowering period in July (stems and inflorescences). Shoots are the young stems that sprouted from the persistent and woody base in spring; leaves, fully expanded, were collected in the median nodes of the annual flowering stems; stems correspond to the herbaceous portion of the annual main stems; inflorescences are the fully developed compound umbels, with fertile flowers and immature seeds.

Morphological key characters from the Iberian Flora (Castroviejo, 2003) were used for plant identification. Voucher specimens were deposited in the Herbarium of the Escola Superior Agrária de Bragança, Portugal. The material was lyophilized (Ly-8FM-ULE, Snijders, HOLLAND) and kept in the best conditions $\left(-20^{\circ} \mathrm{C}, \sim 30\right.$ days) for subsequent use.

\subsection{Standards and reagents}

Acetonitrile $99.9 \%$ pure of HPLC grade was purchased from LabScan (Lisbon, Portugal). Methanol, diethyl ether, toluene and sulphuric acid were of analytical grade purity: The fatty acids methyl ester (FAME) reference standard mixture 37 (fatty acids C4 to C24; standard 47885-U) was from Supelco (Bellefonte, PA, USA) and purchased from Sigma (St. Louis, MO, USA), as well as other individual fatty acid isomers and the sugar standards. All the other chemicals were obtained from Sigma Chemical Co. (St. Louis, MO, USA). Water was treated in a Mili-Q water purification system (TGI Pure Water Systems, USA).

\subsection{Determination of macronutrients}

The samples were analysed for chemical composition (proteins, fat, carbohydrates and ash) using the AOAC (1995) procedures. The crude protein content $(N \times 6.25)$ of the samples was estimated by the macro-Kjeldahl method; the crude fat was determined by extracting a known weight powdered sample with petroleum ether, using a Soxhlet apparatus; the ash content was determined by incineration at $(600 \pm 15){ }^{\circ} \mathrm{C}$; reducing sugars were determined by DNS (dinitrosalicylic acid) method. Total carbohydrates were calculated by difference: Total carbohydrates $=100-($ moisture + proteins + fat + ash $), \quad$ where moisture, proteins, fat and ash, stand for their masses, respectively, expressed in units of $1 \mathrm{~g}$. Total energy was calculated according to the following equation: Energy (Kcal) $=4 \times$ (proteins + carbohydrates $)+9 \times$ (fat), where proteins and carbohydrates stand for their masses, respectively, expressed in units of $1 \mathrm{~g}$.

\subsection{Determination of sugars by HPLC/RI}

\subsubsection{Preparation of standard solutions}

Individual solutions $(\sim 10 \mathrm{mg} / \mathrm{ml})$ of L-arabinose, D-fructose, L-fucose, D-galactose, D-glucose anhydrous, lactose 1-hydrate, maltose 1-hydrate, maltulose monohydrate, D-mannitol, D-mannose, D-melezitose, D-melibiose monohydrate, D-raffinose pentahydrate, L-rhamnose monohydrate, D-sucrose, D-trehalose, D-turanose and D-xylose were prepared in water and stored at $-20^{\circ} \mathrm{C}$. A stock standard mixture with fructose, glucose and sucrose was prepared in water with the final concentration of $30 \mathrm{mg} / \mathrm{ml}$. Melezitose was used as internal standard (IS), being prepared a stock solution $(25 \mathrm{mg} / \mathrm{ml}$ in water) and kept at $\sim 20^{\circ} \mathrm{C}$.

\subsubsection{Extraction procedure}

Dried sample powder $(1.0 \mathrm{~g})$ was spiked with the IS $(5 \mathrm{mg} / \mathrm{ml})$, and was extracted with $40 \mathrm{ml}$ of $80 \%$ aqueous ethanol at $80{ }^{\circ} \mathrm{C}$ for $30 \mathrm{~min}$. The resulting suspension was centrifuged at $15,000 \mathrm{~g}$ for $10 \mathrm{~min}$. The supernatant was concentrated at $60^{\circ} \mathrm{C}$ under reduced pressure and defatted three times with $10 \mathrm{ml}$ of ethyl ether, successively. After concentration at $40^{\circ} \mathrm{C}$, the solid residues were dissolved in water to a final volume of $5 \mathrm{ml}$, filtered through a $0.22 \mu \mathrm{m}$ disposable LC filter disk, transferred into an injection vial and analysed by HPLC.

\subsubsection{HPLC analysis}

The HPLC equipment consisted of an integrated system with a Smartline pump 1000, a Smartline manager 5000 degasser system, a Smartline 2300 RI detector (Knauer, Germany), and an AS-2057 auto-sampler (Jasco, Japan). Data were analysed using Clarity 2.4 Software (DataApex). The chromatographic separation 
was achieved with an Eurospher 100-5 $\mathrm{NH}_{2}$ column $\left(4.6 \mathrm{~mm} \times 250 \mathrm{~mm}, 5 \mathrm{~mm}\right.$, Knauer) operating at $35^{\circ} \mathrm{C}(7971 \mathrm{R}$ Grace oven). The mobile phase used was acetonitrile/deionized water, $7: 3(\mathrm{v} / \mathrm{v})$ at a flow rate of $1 \mathrm{ml} / \mathrm{min}$, and the injection volume was $20 \mu \mathrm{l}$. The compounds were identified by chromatographic comparisons with authentic standards. The results are expressed in $\mathrm{g} / 100 \mathrm{~g}$ of fresh weight, and calculated by internal standard normalization of the chromatographic peak area.

\subsection{Determination of fatty acids by GC/FID}

Fatty acids were determined by gas chromatography with flame ionization detection (GC/FID)/capillary column as described previously by the authors (Barros, Venturini, Baptista, Estevinho, \& Ferreira, 2008), and after the following trans-esterification procedure: fatty acids were methylated with $5 \mathrm{ml}$ of methanol:sulphuric acid:toluene $2: 1: 1(\mathrm{v}: \mathrm{v})$, during at least $12 \mathrm{~h}$ in a bath at $50{ }^{\circ} \mathrm{C}$ with agitation (160 rpm); then $3 \mathrm{ml}$ of deionized water were added, to obtain phase separation; the FAME were recovered with $3 \mathrm{ml}$ of diethyl ether by mixing in vortex , and the upper phase was passed through a micro-column of anhydrous sodium sulphate, in order to eliminate the water; the sample was recovered in a vial with a Teflon cap, and before injection the sample was filtered with $0.2 \mu \mathrm{m}$ nylon filter from Millipore (MA, USA). The fatty acid profile was analysed with a DANI model GC 1000 instrument equipped with a split/splitless injector, a flame ionization detector (FID) and a Macherey-Nagel (PA, USA) column (OPTIMA 225: 50\% cyanopropyl-methyl - 50\% phenylmethylpolysiloxane) with $30 \mathrm{~m} \times 0.32 \mathrm{~mm}$ ID $\times 0.25 \mu \mathrm{m} d_{f}$. The oven temperature program was as follows: the initial temperature of the column was $50^{\circ} \mathrm{C}$, held for $2 \mathrm{~min}$, then a $10^{\circ} \mathrm{C} / \mathrm{min}$ ramp to $240^{\circ} \mathrm{C}$ and held for $11 \mathrm{~min}$. The carrier gas (hydrogen) flow rate was $4.0 \mathrm{ml} / \mathrm{min}(0.61 \mathrm{bar}$ ), measured at $50{ }^{\circ} \mathrm{C}$. Split injection $(1: 40)$ was carried out at $250^{\circ} \mathrm{C}$, and for each analysis $1 \mu \mathrm{l}$ of the sample was injected. Fatty acid identification was made by comparing the relative retention times from samples with FAME peaks (standards). The results were recorded and processed using CSW 1.7 software (DataApex 1.7) and expressed in relative percentage of each fatty acid.

\subsection{Statistical analysis}

For each part of the plant three samples were analysed and all the assays were carried out in triplicate. The results are expressed as mean values and standard deviation (SD). The results were analysed using one-way analysis of variance (ANOVA) followed by Tukey's HSD Test with $\alpha=0.05$. This treatment was carried out using SPSS v. 16.0 software.

\section{Results and discussion}

The macronutrients profiles and the energy contents (expressed on fresh weight basis) of the different parts of fennel (shoots, leaves, stems and inflorescences) are shown in Table 2. Leaves and stems revealed the highest moisture content (76.36 and
$77.46 \mathrm{~g} / 100 \mathrm{~g}$, respectively), while inflorescences showed the lowest content $(71.31 \mathrm{~g} / 100 \mathrm{~g})$. Carbohydrates were the most abundant macronutrients in all the parts and ranged from $18.44 \mathrm{~g} /$ $100 \mathrm{~g}$ in leaves to $22.82 \mathrm{~g} / 100 \mathrm{~g}$ in inflorescences. Reducing sugars are only a small part of carbohydrates due to the abundant presence of polysaccharides such as starch (major polysaccharide used for energy storage in plant cells) and cellulose (structural polysaccharide found as the major component of cell walls in plants) (Zubay, 2006).

Proteins and fat were the less abundant macronutrients; proteins varied between $1.08 \mathrm{~g} / 100 \mathrm{~g}$ in stems and $1.37 \mathrm{~g} / 100 \mathrm{~g}$ in inflorescences. Once more, inflorescences revealed the highest fat content $(1.28 \mathrm{~g} / 100 \mathrm{~g})$ among all the fennel parts. On the basis of the proximate analysis, it can be calculated that a fresh portion of $100 \mathrm{~g}$ of these parts yields, on average, $94 \mathrm{Kcal}$. The highest values were obtained for inflorescences, while leaves and stems gave the lowest energetic contribution (Table 2).

The highest ash content was found in leaves $(3.43 \mathrm{~g} / 100 \mathrm{~g})$, while the lowest value was found in stems $(1.62 \mathrm{~g} / 100 \mathrm{~g})$. This is in agreement with other authors who reported higher levels of minerals in fennel leaves than in fruits (Özcan \& Akbulut, 2007). Several minerals could be included in ash content and particularly, $\mathrm{Ag}, \mathrm{Al}, \mathrm{As}, \mathrm{B}, \mathrm{Ba}, \mathrm{Ca}, \mathrm{Cd}, \mathrm{Co}, \mathrm{Cr}, \mathrm{Cu}, \mathrm{Fe}, \mathrm{In}, \mathrm{K}, \mathrm{Li}, \mathrm{Mg}, \mathrm{Mn}, \mathrm{Na}, \mathrm{Ni}, \mathrm{P}, \mathrm{Pb}$, Se, Sr, Tl, V and Zn were already described in fennel (Özcan et al., 2008). The most abundant minerals found in this plant were $\mathrm{K}, \mathrm{Ca}$, $\mathrm{Mg}, \mathrm{P}$ and $\mathrm{Na}$.

In what concerns sugars composition (Table 3), fructose, glucose and sucrose were detected in all the fennel parts, with the exception of sucrose in stems. These sugars are naturally occurring and widely distributed in plants. Glucose was the most abundant sugar in all the parts, despite the reports of sucrose as the most important sugar in plants. In this study, some percentage of sucrose could have suffered hydrolyze to their monosaccharide's constituents, contributing to an increase in glucose and fructose levels (Table 3). This is in agreement with the results described by Cataldi et al. (1998) reporting D-glucose and D-fructose as mains sugars in fennel. These authors used a different methodology for the analysis: high performance anion-exchange chromatography (HPAEC) coupled with integrated pulsed amperometry using gold working electrodes. In the present study, the separation of all the sugars by HPLC/RI was achieved in only $15 \mathrm{~min}$, faster than the 25-35 min described by other authors (Cataldi et al., 1998).

Shoots revealed the highest concentration of sugars $(6.57 \mathrm{~g} /$ $100 \mathrm{~g}$ ) due to the contribution of fructose, glucose and sucrose. Otherwise, leaves revealed the lowest content $(1.29 \mathrm{~g} / 100 \mathrm{~g})$. This decrease in sugars content could be explained by the fact that the collected leaves were in a mature growth stage, consuming sugars for the photosynthetic process.

Total sugars (Table 3 ) were higher than reducing sugars (Table 2) due to the contribution of non reducing sugars such as sucrose.

The results of fatty acid composition, total saturated fatty acids (SFA), monounsaturated fatty acids (MUFA), and polyunsaturated fatty acids (PUFA) of the different parts of fennel are shown in Table 4. The most abundant fatty acid in shoots, stems and

Table 2

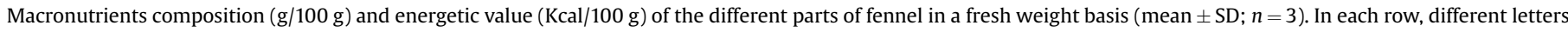
mean significant differences $(p<0.05)$.

\begin{tabular}{|c|c|c|c|c|}
\hline & Shoots & Leaves & Stems & Inflorescences \\
\hline Moisture & $73.88 \pm 0.83$ ba & $76.36 \pm 0.33 a$ & $77.46 \pm 1.03 \mathrm{a}$ & $71.31 \pm 4.01 \mathrm{~b}$ \\
\hline Ash & $2.39 \pm 0.02 c$ & $3.43 \pm 0.04 \mathrm{a}$ & $1.62 \pm 0.12 \mathrm{~d}$ & $3.23 \pm 0.02 \mathrm{~b}$ \\
\hline Fat & $0.49 \pm 0.05 b$ & $0.61 \pm 0.16 b$ & $0.45 \pm 0.07 b$ & $1.28 \pm 0.28 \mathrm{a}$ \\
\hline Proteins & $1.33 \pm 0.04 \mathrm{a}$ & $1.16 \pm 0.03 b$ & $1.08 \pm 0.00 \mathrm{~b}$ & $1.37 \pm 0.05 \mathrm{a}$ \\
\hline Carbohydrates & $21.91 \pm 0.55$ ba & $18.44 \pm 0.06 \mathrm{~b}$ & $19.39 \pm 0.65$ ba & $22.82 \pm 3.06 \mathrm{a}$ \\
\hline Reducing sugars & $1.14 \pm 0.10 \mathrm{~b}$ & $0.72 \pm 0.04 c$ & $1.49 \pm 0.29 a$ & $1.20 \pm 0.19 b$ \\
\hline Energy & $97.37 \pm 2.44$ ba & $83.90 \pm 1.34 b$ & $85.91 \pm 3.02 b$ & $108.23 \pm 10.37 \mathrm{a}$ \\
\hline
\end{tabular}


Table 3

Sugars composition ( $\mathrm{g} / 100 \mathrm{~g}$ of fresh weight) of the different parts of fennel (mean $\pm S D ; n=3$ ). In each row, different letters mean significant differences $(p<0.05)$.

\begin{tabular}{lllll}
\hline & Shoots & Leaves & Stems & Inflorescences \\
\hline Fructose & $1.51 \pm 0.06 \mathrm{a}$ & $0.49 \pm 0.05 \mathrm{c}$ & $1.49 \pm 0.04 \mathrm{a}$ & $1.10 \pm 0.04 \mathrm{~b}$ \\
Glucose & $4.71 \pm 0.15 \mathrm{a}$ & $0.76 \pm 0.12 \mathrm{~d}$ & $3.43 \pm 0.20 \mathrm{~b}$ & $2.94 \pm 0.11 \mathrm{c}$ \\
Sucrose & $0.35 \pm 0.06 \mathrm{a}$ & $0.04 \pm 0.00 \mathrm{~b}$ & nd & $0.03 \pm 0.00 \mathrm{~b}$ \\
Total sugars & $6.57 \pm 0.17 \mathrm{a}$ & $1.29 \pm 0.20 \mathrm{~d}$ & $4.92 \pm 0.23 \mathrm{~b}$ & $4.07 \pm 0.16 \mathrm{c}$ \\
\hline
\end{tabular}

nd - not detected.

inflorescences was linoleic acid (C18:2), followed by $\alpha$-linolenic (C18:3) and palmitic (C16:0) acids. Otherwise, $\alpha$-linolenic acid predominated in leaves (43.55\%). Vardavas et al. (2006) also reported the prevalence of $\alpha$-linolenic acid followed by oleic and palmitic acids in a Greece fennel sample. Besides the three main mentioned fatty acids, eighteen more were identified and quantified. PUFA were the main group of fatty acids in all the fennel parts (Table 4). Other authors reported MUFA as the main group of fatty acids in fennel (Vardavas et al., 2006). Nevertheless, UFA ranged from $66 \%$ to $80 \%$, and predominated over SFA.

Linoleic acid is an essential fatty acid and originates the omega- 6 fatty acids series. The dietary $\omega-6$ fatty acids are associated with a lower prevalence of hypertension and lower systolic blood pressure (Djousse et al., 2005). Studies reveal that dietary $\omega-6$ fatty acids play a role in nerve conduction velocity due to their incorporation in membrane phospholipids (Coste et al., 1999 ) and posses antitumor properties against prostate (Bidoli et al., 2005), breast (Menendez, Ropero, Lupu, \& Colomer, 2004) and pancreas cancers (Agombar, Cooper, \& Johnson, 2004), among others.

Table 4

Percentages of the total detected fatty acids in the different parts of fennel. The results are expressed as mean $\pm S D(n=3)$. In each column different letters mean significant differences $(p<0.05)$

\begin{tabular}{lrrrr}
\hline \multicolumn{1}{c}{ Shoots } & \multicolumn{1}{l}{ Leaves } & \multicolumn{1}{l}{ Stems } & Inflorescences \\
\hline C6:0 & $0.06 \pm 0.00$ & $0.02 \pm 0.00$ & $0.19 \pm 0.01$ & $0.41 \pm 0.02$ \\
C8:0 & $0.33 \pm 0.00$ & $0.08 \pm 0.00$ & $0.48 \pm 0.03$ & $0.37 \pm 0.01$ \\
C10:0 & $0.06 \pm 0.00$ & $0.04 \pm 0.00$ & $0.13 \pm 0.01$ & $0.09 \pm 0.00$ \\
C11:0 & $0.07 \pm 0.00$ & $0.25 \pm 0.02$ & $0.04 \pm 0.00$ & $0.29 \pm 0.01$ \\
C12:0 & $0.21 \pm 0.02$ & $0.31 \pm 0.02$ & $0.11 \pm 0.01$ & $0.43 \pm 0.06$ \\
C14:0 & $0.75 \pm 0.03$ & $1.43 \pm 0.01$ & $0.49 \pm 0.06$ & $1.68 \pm 0.10$ \\
C14:1 & $0.17 \pm 0.03$ & $0.61 \pm 0.04$ & $0.37 \pm 0.04$ & $0.28 \pm 0.02$ \\
C15:0 & $0.18 \pm 0.00$ & $0.17 \pm 0.00$ & $0.41 \pm 0.04$ & $0.35 \pm 0.03$ \\
C16:0 & $12.78 \pm 0.09$ & $20.15 \pm 0.09$ & $25.43 \pm 0.00$ & $23.89 \pm 0.07$ \\
C17:0 & $0.24 \pm 0.02$ & $0.74 \pm 0.00$ & $0.61 \pm 0.04$ & $0.58 \pm 0.02$ \\
C18:0 & $1.53 \pm 0.08$ & $1.61 \pm 0.08$ & $1.99 \pm 0.06$ & $2.62 \pm 0.04$ \\
C18:1n9c & $2.55 \pm 0.33$ & $4.35 \pm 0.37$ & $4.35 \pm 0.52$ & $5.05 \pm 0.00$ \\
C18:2n6c & $39.99 \pm 0.68$ & $23.25 \pm 0.07$ & $38.22 \pm 0.68$ & $38.94 \pm 0.23$ \\
C18:3n3 & $36.84 \pm 0.52$ & $43.55 \pm 0.40$ & $22.86 \pm 1.31$ & $17.55 \pm 0.00$ \\
C20:0 & $1.06 \pm 0.09$ & $0.56 \pm 0.00$ & $0.84 \pm 0.03$ & $1.78 \pm 0.06$ \\
C20:1c & $n d$ & $n d$ & $0.06 \pm 0.00$ & $0.26 \pm 0.03$ \\
C20:2c & $0.38 \pm 0.07$ & $0.08 \pm 0.01$ & $0.14 \pm 0.00$ & $0.31 \pm 0.01$ \\
C20:3n3+C21:0 $0.12 \pm 0.01$ & $0.16 \pm 0.02$ & $0.19 \pm 0.00$ & $0.15 \pm 0.01$ \\
C22:0 & $1.12 \pm 0.02$ & $0.77 \pm 0.04$ & $1.20 \pm 0.03$ & $1.52 \pm 0.04$ \\
C23:0 & $0.36 \pm 0.15$ & $0.82 \pm 0.13$ & $0.68 \pm 0.01$ & $1.89 \pm 0.11$ \\
C24:0 & $1.20 \pm 0.08$ & $1.03 \pm 0.04$ & $1.21 \pm 0.02$ & $1.58 \pm 0.02$ \\
Total SFA & $19.95 \pm 0.12 \mathrm{~d}$ & $27.99 \pm 0.02 \mathrm{c}$ & $33.81 \pm 0.06 \mathrm{~b}$ & $37.47 \pm 0.25 \mathrm{a}$ \\
Total MUFA & $2.72 \pm 0.36 \mathrm{c}$ & $4.96 \pm 0.40 \mathrm{ba}$ & $4.78 \pm 0.57 \mathrm{~b}$ & $5.59 \pm 0.13 \mathrm{a}$ \\
Total PUFA & $77.33 \pm 0.24 \mathrm{a}$ & $67.05 \pm 0.42 \mathrm{~b}$ & $61.41 \pm 0.62 \mathrm{c}$ & $56.94 \pm 0.12 \mathrm{~d}$ \\
\hline
\end{tabular}

nd- not detected.

Caproic acid (C6:0); Caprylic acid (C8:0); Capric acid (C10:0); Undecanoic acid (C11:0); Lauric acid (C12:0); Myristic acid (C14:0); Myristoleic acid (C14:1); Pentadecanoic acid (C15:0); Palmitic acid (C16:0); Heptadecanoic acid (C17:0); Stearic acid (C18:0); Oleic acid (C18:1n9c); Linoleic acid (C18:2n6c); $\alpha$-Linolenic acid (C18:3n3); Arachidic acid (C20:0); Eicosanoic acid (C20:1); cis-11,14-Eicosadienoic acid (C20:2c); cis-11,14,17-Eicosatrienoic acid + Heneicosanoic acid (C20:3n3 + C21:0); Behenic acid (C22:0); Tricosanoic acid (C23:0); Lignoceric acid (C24:0).
Table 5

$\omega 3$ and $\omega 6$ content (percent) in the different parts of fennel. The results are expressed as mean $\pm S D(n=3)$. In each row different letters mean significant differences $(p<0.05)$.

\begin{tabular}{lrrrr}
\hline & \multicolumn{1}{l}{ Shoots } & \multicolumn{1}{l}{ Leaves } & \multicolumn{1}{l}{ Stems } & \multicolumn{1}{l}{ Inflorescences } \\
\hline$\omega 3$ & $36.96 \pm 0.51 \mathrm{~b}$ & $43.72 \pm 0.36 \mathrm{a}$ & $23.04 \pm 1.30 \mathrm{c}$ & $17.69 \pm 0.01 \mathrm{~d}$ \\
$\omega 6$ & $39.99 \pm 0.68 \mathrm{a}$ & $23.25 \pm 0.07 \mathrm{c}$ & $38.22 \pm 0.68 \mathrm{~b}$ & $38.94 \pm 0.23 \mathrm{~b}$ \\
$\omega 6 / \omega 3$ & $1.08 \pm 0.03 \mathrm{c}$ & $0.53 \pm 0.00 \mathrm{~d}$ & $1.66 \pm 0.12 \mathrm{~b}$ & $2.20 \pm 0.01 \mathrm{a}$ \\
\hline
\end{tabular}

$\alpha$-Linolenic is an essential fatty acid and it is precursor of the omega-3 fatty acids series in humans. Essential $\omega-3$ fatty acids revealed antitumor properties against various types of cancers including breast (Klein et al., 2000), prostate (Terry, Terry, \& Rohan, 2004) and colorectal cancers (Reddy 2004). Furthermore, dietary $\omega-3$ fatty acids possibly play a vital role in inflammatory diseases, hypertension and coronary heart disease (Dokholyan et al., 2004; Wijendran \& Hayes, 2004).

The highest concentration of n-3 fatty acids was found in fennel leaves, while the lowest concentration was found in inflorescences (Table 5). The ratio of $\omega-6$ to $\omega$-3 fatty acids has an important role in the human diet, and is also presented in Table 5. The highest levels of n-3 fatty acids found in leaves contributed to its lowest ratio of $\omega$ 6 to $\omega-3$ fatty acids. The lowest levels of n-3 fatty acids found in inflorescences contributed to its highest ratio of $\omega-6$ to $\omega-3$ fatty acids. Leaves were the only part presenting a ratio lower than 1 (0.53), and even lower than the ratio reported by Vardavas et al. (2006) in a Greece sample of fennel (0.89). Those authors stated that low ratios could reduce the potential for lung cancer, asthma and may prevent thrombosis and atherosclerosis; while a high serum n-6:n-3 ratio is associated with major depression and may increase the risk of coronary heart disease (Vardavas et al., 2006).

The studied plant plays an important role in the traditional diet of the Portuguese rural areas, mainly in Trás-os-Montes and Alentejo since fennel is daily consumed, raw in salads and snacks, or stewed, boiled, grilled or baked in several dishes and drunk as herbal teas or spirits. A diet rich in this perennial umbelliferous herb could bring potential health benefits due to their valuable nutritional composition in essential fatty acids. The sugars identified in the samples, such as glucose and fructose, occupy key roles in the energetic metabolism and supply carbon skeletons for the synthesis of other compounds. As far as we know, nothing has been reported on macronutrients composition of all the fennel parts: shoots, leaves, stems and inflorescences.

\section{Acknowledgements}

The authors are grateful to the Foundation for Science and Technology (Portugal) for financial support to the research centre CIMO and L. Barros grant (SFRH/BPD/4609/2008).

\section{References}

Agombar, A., Cooper, A. J., \& Johnson, C. D. (2004). An aqueous formulation of gamma-linolenic acid with anti-proliferative action on human pancreatic cancer cell lines. Anticancer Drugs, 15, 157-160.

AOAC. (1995). Official methods of analysis (16th ed.). Arlington, VA, USA: Association of Official Analytical Chemists.

Barros, L., Venturini, B., Baptista, P., Estevinho, L., \& Ferreira, I. C. F. R. (2008). Chemical composition and biological properties of Portuguese wild mushrooms: a comprehensive study. Journal of Agricultural and Food Chemistry, 56, 3856-3862.

Bidoli, E., Talamini, R., Bosetti, E., Negri, E., Maruzzi, D., Montella, M., et al. (2005). Macronutrients, fatty acids, cholesterol and prostate cancer risk. Annals of Oncology, 16, 152-157.

Camejo-Rodrigues, J. S., Ascensão, L., Bone, T. M.À., \& Vallès, J. (2003). An ethnobotanical study of medicinal and aromatic plants in the Natural Park of Serra de S. Mamede (Portugal). Journal of Ethnopharmacology, 89, 199-209. 
Carvalho, A. M. (2005). Etnobotánica del Parque Natural de Montesinho. Plantas, tradición y saber popular en un territorio del nordeste de Portugal. Madrid: Universidad Autónoma.

(coord.) Castroviejo, S. (2003). Flora Iberica. Madrid: Real Jardín Botánico, CSIC

Cataldi, T. R. I., Margiotta, G., \& Zambonin, C. G. (1998). Determination of sugars and alditols in food samples by HPAEC with integrated pulsed amperometric detection using alkaline eluents containing barium or strontium ions. Food Chemistry, 62, 109-115.

Coste, T., Pierlovisi, M. Leonardi, J., Dufayet, D., Gerbi, A., Lafont, H., et al. (1999) Beneficial effects of gamma linolenic acid supplementation on the nerve conduction velocity, $\mathrm{Na}^{+}, \mathrm{K}^{+}$ATPase activity, and membrane fatty acid composition in sciatic nerve of diabetic rats. Journal of Nutritional Bio-Chemistry, 10, 411-420.

Djousse, L., Arnett, D. K., Pankow, J. S., Hopkins, P. N., Province, M. A., \& Ellison, R. C. (2005). Dietary linolenic acid is associated with a lower prevalence of hypertension in the NHLBI family heart study. Hypertension, 45, 368-373.

Dokholyan, R. S., Albert, C. M., Appel, L. J., Cook, N. R., Whelton, P., \& Hennekens, C. H. (2004). A trial of omega-3 fatty acids for prevention of hypertension. American Journal of Cardiology, 93, 1041-1043.

Gibney, M. J., Vorster, H. H., \& Kok, F. J. (2002). Introduction to human nutrition. Oxford: Blackwell Science.

Kaplan. (1996). Clinical chemistry - Theory, analysis, correlation. In. Missouri (3rd ed).. Mosby Ed.

Klein, V., Chajes, V., Germain, E., Schulgen, G., Pinauk, M., Malvy, D., et al. (2000). Low alpha-linolenic acid content of adipose breast tissue is associated with an increased risk of breast cancer. European Journal of Cancer, 36, 335-340.

Menendez, J. A., Ropero, S., Lupu, R., \& Colomer, R. (2004). Omega-6 polyunsaturated fatty acids gamalinoleic acid (18:3 n-6) enhances docetaxel (Taxotere) cytotoxicity in human breast carcinoma cells: relationship to lipid peroxidation and HER-2/neu expression. Oncology Reports, 11, 1241-1252.

Novais, H. M., Santos, I., Mendes, S., \& Pinto-Gomes, C. (2004). Studies on pharmaceutical ethnobotany in Arrábida Natural Park. Journal of Ethnopharmacology, 93, 183-195.
Oktay, M., Gülçin, I., \& Küfrevioğlu, Ö. I. (2003). Determination of in vitro antioxidant activity of fennel (Foeniculum vulgare) seed extracts. Lebensm.-Wiss U.-Technology, 36, 263-271.

Özcan, M. M., \& Akbulut, M. (2007). Estimation of minerals, nitrate and nitrite contents of medicinal and aromatic plants used as spices, condiments and herbal tea. Food Chemistry, 106, 852-858.

Özcan, M. M., Ünver, A., Uçar, T., \& Arslan, D. (2008). Mineral content of some herbs and herbal teas by infusion and decoction. Food Chemistry, 106, 1120-1127.

Reddy, B. S. (2004). Omega-3 fatty acids in colorectal cancer prevention. International Journal of Cancer, 112, 1-7.

Salgueiro, J. (2004). Ervas, usos e saberes. Lisboa: MARCA, Associação de Desenvolvimento Local.

Santayana, M. P., Tardio, J., Blanco, E., Carvalho, A. M., Lastra, J. J., San Miguel, E., et al. (2007). Traditional knowledge of wild edible plants used in the northwest of the Iberian Peninsula (Spain and Portugal): a comparative study. Journal of Ethnobiology and Ethnomedicine, 3, 27-37.

Tardío, J., Pardo de Santayana, M., \& Morales, R. (2006). Ethnobotanical review of wild edible plants in Spain. Botanical Journal of the Linnean Society, 152, 27-71.

Tardío, J., Pascual, H. M., \& Morales, R. (2005). Wild food plants traditionally used in the province of Madrid, Central Spain. Economic Botany, 59(2), 122-136.

Terry, P. D., Terry, J. B., \& Rohan, T. E. (2004). Long-chain (n-3) fatty acid intake and risk of cancers of the breast and prostate: recent epidemiological studies, biological mechanisms, and directions for future research. Journal of Nutrition, 134, 3412S-3420S.

Vardavas, C. I., Majchrzak, D., Wagner, K. H., Elmadfa, I., \& Kafatos, A. (2006) Lipid concentrations of wild edible greens in Crete. Food Chemistry, 99, $822-834$

Veigas, M. (2007). Aromas e sabores de Cuba. Évora: Câmara Municipal de Cuba. Wijendran, V., \& Hayes, K. C. (2004). Dietary n-6 and n-3 fatty acid balance and cardiovascular health. Annual Review of Nutrition, 24, 597-615.

Zubay, G. (2006). Biochemistry (5th ed.). Wm. C. Brown Publishers. 